\title{
・特集 続・環境時代へのゴム材料・ゴム製品
}

\section{環境時代への材料開発}

内 藤 壽 夫*

\section{1.はじめに}

\section{1 地球環境問題}

20 世紀後半から世紀末にかけて噴出した多く の環境問題は地球温暖化，オゾン層破壊，森林等 再生可能な資源の言失, 砂漠化, 人間以外の動植 物の急激な絶滅など, 多数の困難な課題を抱えた ままあと数か月余りで 21 世紀を迎えようとして いる. 最近の状況は東大石 弘之教授の近著, 「地球環境報告・II」1)に生々しくレポートされて いる. 地球規模の環境問題は，残念ながら既得権 にしがみついて動かない先進国，環境問題にはあ る程度目をつむり，先進国に一歩でも追いつきた い後進国の利害が皮肉にも一致して，昨年 11 月 アルゼンチンで開催された COP 4 (Conference of Parties)でも，あまり有効な結論が得られな いまま終了した。しかし，地球温暖化が主に人間 の活動に基づくものであるという報道は日々に多 くなっており2)，予想されたように巨大台風，巨 大竜巻, 各地における洪水が頻発し, 大きな被害 が報告されている。この現象は 1980 年代後半か ら顕著となり，指数関数的に増大している. 昨年 は世界中でついに 10 兆円を超す被害, 3 億人が 家を失うか損害を受け， 3 万〜 5 万人が死亡した といわれる ${ }^{3,4)}($ 図 1).人間の経済活動による地 球温暖化を否定し，太陽黒点運動の所為であると か5), 人間活動の寄与は取るに足らないという説 もアメリカ中心にいまだ存在するが次第に勢いを 失いつつあるように思われる。

環境問題に関して発言することは非常に難し い.あまりにも複雑で，相手が大きく，自ら真偽
を確かめることが極めて難しいからである．筆者 は以下に記すような事態が起こらないことを心よ り願っているが，先に述べたような気象の異常が 指数関数的に続けば農業生産へ大きな影響を与え る可能性が高い。食糧自給率 $40 \%$, 電気エネル ギー自給率 $9 \%$ といわれる我が国のリスク管理の お粗末さ(国レベルでも，個人レベルでも殆んど

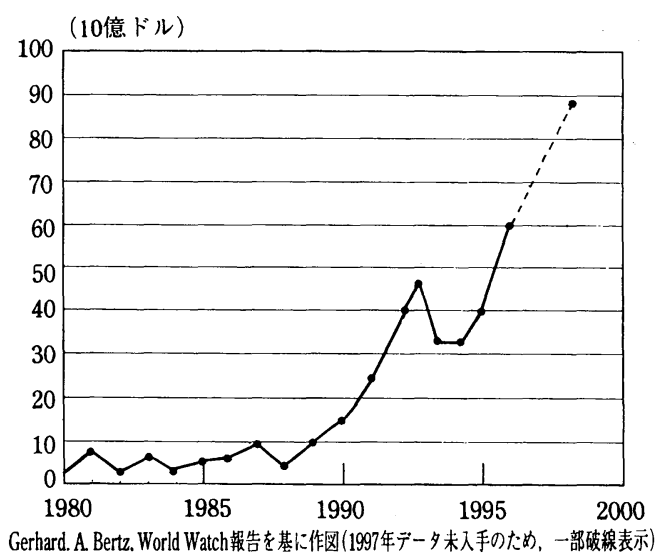

园 1 急増する世界の気象災害

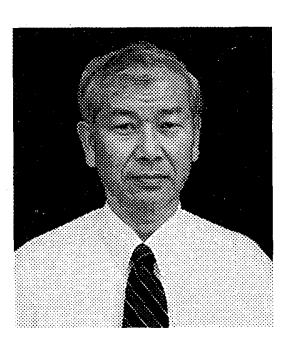

*内藤技術士事務所長 ( $7216-0035$ 川崎市宮前区馬絹969-1) 工博. 技 術士(化学部門). ISO14001主任審 查貝. 昭和 42 年東京大学農学系修 士修了。同年ブリヂストンタイヤ 秼入社. 夕イヤ材料部を経て研究 開発本部研究部長. 平成 10 年より 技術士事務所開設. 昭和51年より 2 年間ベルテレフォン研究所客員 研究員. 専門はゴムの構造と物性, 接着と表面処理技術。 日本ゴム協会前評議員. 
表 1 日本におけるエネルギー消費の増加 (概略指標)

\begin{tabular}{c|c|c|c|c|c}
\hline & 民生(家庭) & 民生(業務) & 運輸 & 産業 & 全体 \\
\hline 1984 & 100 & 100 & 100 & 100 & 100 \\
1994 & 120 & 170 & 160 & 112 & 139 \\
\hline
\end{tabular}

ないに等しい)には寒気を催さざるを得ない。（余 っているはずの)米の，平年対比 $10 \%$ に満たな い不作で大騒ぎをしたのは $5 ， 6$ 年前のことであ る。その日暮らしで「出たとこ勝負」の対応は国 民性なのであろうか？ 国民も上記の事態を認識 せず，相変わらず高エネルギー，高資源消費型の 生活スタイルに酔い痴れているかに見える(表 1 , 図 2 ).

東大山本良一教授の指摘されるように化石工ネ ルギー，鉱物資源の残存可採可能年数もいよいよ はっきりし出しており，鉱石のトンあたり含有量 は減少して価格の高騰は必至である、ゴム産業で は亜鉛の動向に注目しておく必要がありそうであ る.また人口爆発もやや予想を下回っているが, 年間約 8000 万人が増加している。（よく後進国の 人口増加だけが問題にされるが，先進国の資源と エネルギーの一人あたり使用は後進国のそれの 8 ～10 倍に達する).

世界的には 1992 年, ブラジルのリオサミット で約 170 か国が参加してまとめられた「アジェン

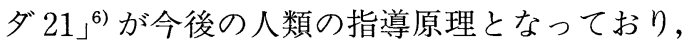
欧州などでは経営者も多くこれを読んでいるよう であるが，残念ながら日本では殆んど顧みられて いないように見える。

\section{2 大量生産/大量消費経済の破綻}

20 世紀は資源，エネルギー，廃棄に制約を感 じずに，大量生産，大量消費，大量廃棄型産業が 経済を支配してきた。この結果先進国では豊かさ と利便性を享受し，アメリカ型の生活ス夕イルは 全人類のあこがれと目標となった。いくつかの 国々ではこうした経済と資源，エネルギー，環境 との調和を四らねば，全人類の危機が現実となる ことに目覚めているものの, 地球環境問題の存在 すら率直に認めようとしない先進国の一部産業 界，認めはするがいまだ差し迫っていないと考え る多くの既存産業, 物質文明という麻薬にあこが れる発展途上国，遅れる大衆の意識，などが妨げ となって一進一退の事態が続いているのが現状と

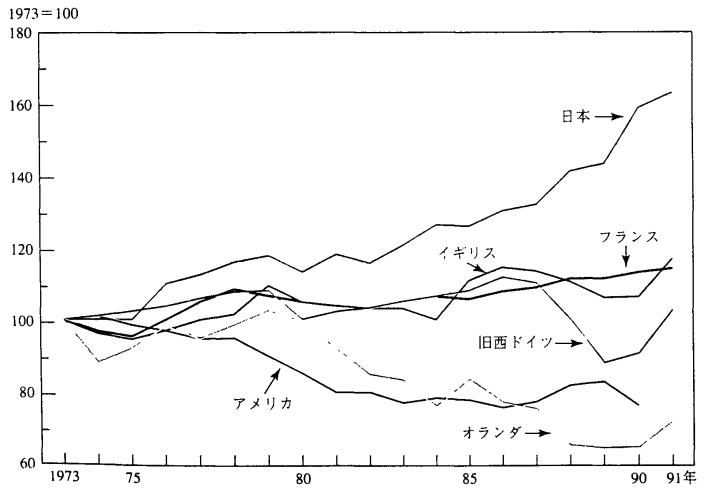

捠料：(財) 日本エネルギー経済研究所

図 2 一人あたり家庭用エネルギー消費推移の国際比較

いえる. 日本はアメリカ型産業への追従からいち 早く抜け出して知識集約型の産業, 特に食糧問題 への対応を含んだ広義での環境技術産業の振興に 全力を尽くすことが望ましく，生き残りの道では ないかと考える。例えば徹底した低燃費自動車の 開発は自動車産業の生き残りにつながる，世界的 な業界再編成もこうした技術を軸に行われる兆し がすでに見えている.

\section{2 . 今後の社会}

\section{1 リスクと利便性}

利便性を追求し続けてきた現代社会は，一方で リスクと背中合わせの社会といえる．多くの化学 物質は人類に多くの貢献をし，先進国における高 い農業生産性(1ヘクタールあたり約 $5 \mathrm{t}$ ) は農薬 や化学肥料なしには不可能とされる。また，医薬 や殺虫剂がマラリア等から救った人命は億の単位 になると推定される。しかし化学物質の副作用も 最近次々に明らかとなり，また非意困的生産物で あるダイオキシン, 環境ホルモン問題は社会問題 化している，原子力もまさにリスクと背中合わせ のエネルギーといえよう。リスクゼロは理想では あるが，現実にはありえない(減少への努力は必 要, 例: 航空機事故). 横浜国大中西教授の指摘 されるように7)，ベネフィットとリスクに関する 管理やバランスに関する社会的合意の欠如が混乱 に拍車をかけている.

\section{2 何が人間にとって根源的か}

今後の社会は, 人間にとって何が最も根源的に 大切かを改めて真剣に問い直さねばならない。こ 
れは何もストイックな生活をせよ，画一的な価値 観をもてと主張しているわけではない。まず何よ ク日本人を含む人類の生存を可及的に保証しなけ ればならない。エネルギー, 資源, 食糧(水，耕 地, 肥料, 天候の不安定への対処), 住居, 衣服, 生活物資などの確保に関する長期的シナリオが必 要である．江戸時代は太陽の恵みの範囲，自然循 環のなかで暮らしてきたが，人口は約 3000 万で あったと推定されている. 現在の日本の人口 1 億 2 千万はいつまで，どのようなエネルギー，食糧 政策のなかで支えられるであろうか. 高齢化，少 子化も問題ではあるが世界的な食糧供給が逼迫し たとき一体どう対応するのであろうか（食糧供給 に関してはレスター・ブラウンらの悲観論 ${ }^{8)}$ と, 世界銀行などの楽観論9 ${ }^{9}$ がある)。残念ながらこ うした根本的なことに関して今日の日本の政治家 が発言したのを聞いたことがない。生存の次はリ プロダクション(種，民族の保存)，次いで哲学 (生きがい)，満足感，精神的な楽しみ，宗教，芸 術といった精神活動に関する充足なくては人間と はいえない，また，スポーツ，趣味，旅行といっ た活動をエネルギーや資源，環境保全の制約のな かでどこまで可能にするか，我々に課せられた課 題は極めて重く幅広い．食糧やエネルギーに対す る懸念は決して杞憂ではなく，極めて差し迫った 問題となりつつあることを強調したい。このまま では現在 40 代の人々が 80 歳まで満足に一生を送 れる可能性は高くない。

\section{3 変化する社会と国際的な対応}

ビジネスとリンクして一番大きな鍵は国際的な 標準への対応である。品質マネジメントシステム に関する ISO 9000，環境マネジメントシステム の 14001 両規格はこれまでの日本の御神興経営と は異なり，トップの明確な方針，資源の用意，経 営者自身のシステムの見直しを要求している。情 報や運営に関する透明性の確保はビジネスにおい て日本人に最も苦手とするところで，情報公開の 不手際で内外の不信を買っている例が余りにも多 い.

\section{4 温暖化対策と社会}

政府も温暖化対策に無為無策というわけではな く，種々の法令，テーマ設定など(表 2 )を行って いる．省エネ法では初めてトップランナ一方式が 採用されている(例えば $\mathrm{A}$ 社のエアコンが最もエ ネルギー使用効率で優れていたとすると，その值

\section{表 2 温暖化対策技術課題}

\begin{tabular}{l} 
ハイブリッド自動車の普及 \\
原子力発電の安全性向上 \\
自然エネルギー利用促進 $($ 太陽光発電・風力発電・地熱発 \\
電など) \\
都市・工場廃熱回収利用技術 \\
低エネルギー消費機器, 家電, モーターの開発促進 \\
ボイラーとガスービンの複合化 \\
高効率ガスタービン \\
高速増殖炉発電 \\
超低消費電力 LSI の開発 \\
ダイオキシンのでない高効率廃棄物発電 \\
蓄熱材料の開発 \\
燃料電池の実用化 \\
植林技術・緑化技術 \\
バイオマスの利用 \\
代替フロンに代わる物質開発 \\
6 フッ化硫黄代替物質の開発 \\
低コスト高効率太陽光発電 \\
水素燃料電池自動車 \\
超電導関連技術の利用 \\
メタンハイドレートの資源化 \\
ニ酸化炭素固定・分離・処分技術 \\
太陽エネルギーなど自然エネルギー使用の水素製造 \\
宇宙空間太陽光発電 \\
\hline
\end{tabular}

が目標となる。これが繰り返されるので省エネ改 善が進む)。問題は時間との競争で，我々に残さ れている時間は非常に少ない。表 3 に温暖化の国 民生活への影響を簡単にまとめてみた。

しかしこれらは見方を変えれば新しいビジネス の芽が多数含まれていることを意味する，広義の 環境技術，産業を興して雇用を吸収しない限り変 革は進まない。

\section{3 . 今後の物作り}

上記のような現状，また未来認識に立つと，日 本の科学技術の取り組むべき優先課題は明らかで あると思われる。科学技術基本法の成立以来，大 学などへの予算配分はかなり増加したと伝えられ ているが，日本にとってもっと足下を見定めたテ 一マへの配分が重視されてしかるべきではなかろ うか. エネルギー, 食糧, 環境 (広義)に関するテ 一マなどは資源配分を増やすとともに，成果につ いても国民的関心が払われなければならない，今 後の物作りは，できるだけ上記の基本的なテーマ に係わるものであることが望ましい，人間生活に 対する一次的な重要性をもっと認識する必要があ る. 批判覚悟でいうならば，高機能性材料やデバ 
表 3 温暖化防止策と国民生活への影響

\begin{tabular}{|c|c|c|c|}
\hline 業界 & 対応策 & 国民生活への影響 & 問題点と新ビジネスの可能性 \\
\hline 自動車 & 低公害車の開発と販売促進 & 価格上昇の恐れ & 新たな世界競争力の付加 \\
\hline 電機 & 待機電力の大幅削減/廃止 & 利便さの犠牲 & 省エネ半導体の開発 \\
\hline 電子 & 非温暖化冷媒の開発と使用 & 製品価格上昇 & \\
\hline \multirow[t]{2}{*}{ 鉄鋼 } & エネルギー消費の削減 & 地域冷暖房の拡大 & \\
\hline & プラスチック廃棄物の利用 & ゴミ問題の軽減 & 廃棄物処理ビジネス \\
\hline 化学 & 生産量の低減 & 製品価格の上昇 & $\begin{array}{l}\text { 長寿命品の開発 } \\
\text { 二酸化炭素固定化技術 }\end{array}$ \\
\hline \multirow[t]{2}{*}{ 住宅 } & 省エネ住宅の普及 & 住宅価格の上昇 & 断熱材の使用増加 \\
\hline & 太陽エネルギーの最大利用 & & $\begin{array}{l}\text { 複層ガラスの普及 } \\
\text { 熱線反射材料の使用拡大 }\end{array}$ \\
\hline \multirow[t]{5}{*}{ 電力 } & 原発の増設 & & 原発に対する国民の不信 \\
\hline & 新エネルギー開発の促進 & & 感と立地難 \\
\hline & 太陽光 & & 太陽光発電関連ビジネス \\
\hline & 風力 & & 風力発電関連ビジネス \\
\hline & 地熱 & & \\
\hline \multirow[t]{3}{*}{ 流通 } & 共同配送の促進 & 配達時間の増大 & \\
\hline & $\begin{array}{l}\text { 媣夜営業の制限 (コンビニ，ファミ } \\
\text { リーレストラン) }\end{array}$ & 利便さの減少 & \\
\hline & スーパー, デパートの営業時間短縮 & & \\
\hline \multirow[t]{3}{*}{ 運輸 } & 低公害車の導入 & & 低公害車関連部品産業 \\
\hline & アイドリングの防止 & & 待機時冷暖房技術開発 \\
\hline & $\begin{array}{l}\text { 電車，バスなど公的機関利用増大 } \\
\text { 自家用車の都心乗り入れ制限 } \\
\text { ガソリンスタンドの営業制限 }\end{array}$ & 利便さの減少 & $\begin{array}{l}\text { 鉄道の復活, 鉄道貨物の復 } \\
\text { 権, レンタカーの増大 }\end{array}$ \\
\hline \multirow[t]{5}{*}{ その他 } & 海外旅行の制限 & & $\begin{array}{l}\text { 旅行権の売買ビジネス } \\
\text { 国内旅行業の復権 }\end{array}$ \\
\hline & サマータイムの導入 & 生活スタイルの変更 & \\
\hline & 植林の推進 & & 造林業の復権 \\
\hline & 自動販売機の制限 & 利便さの減少 & \\
\hline & パチンコ過㮃照明, 装飾照明の制限 & 潤いの減少 & \\
\hline
\end{tabular}

イス等ばかりに目を向けず，今後我々にとって本 質的な問題にも取り組んで欲しいと思う.

\section{1 もの作りで配慮すべき事項}

具体的な物作りに際し，考慮しなければならな い事項は少なくない，以下に列挙すると，

1）エネルギー，資源の有限性に配慮し，その使 用に関し徹底した効率化をはかること，

2 ）設計段階からリニューアル・リユース・レデ ユース・リペアを考えること. 環境配慮設計 (Design for Environment : DFE) は材料, 構造設 計の如何を問わず不可欠となる. DFEに関し ISO で規格化の動きが出始めている，表 4 に環 境配慮設計指針の一例を示した ${ }^{10)}$.
3 ) 溶媒を含む化学物質において特に重要なのは その副作用, 潜在的副作用を考慮し, 必ずその使 用を記録すること。このことは法制化が進められ ている PRTR (環境污染物質排出・移動登録)に備 える意味もある. PRTR では, 約 170 種類の化 学薬品や溶媒が取り上げられている.ゴム工業に 直接，間接に関係するものを抜粋して表 5 に示 す.

4 ）毒性, あるいは副作用のある化学物質, 溶媒 の使用を中止, 又は減少, 適正管理の徹底をはか ること.このことは最近ひろまりつつあるグリー ン調達に関しても極めて重要である。一部の業界 では消費者に与えるイメージを重視し, 科学的裏 
表 4 製品の環境対応設計指針

\begin{tabular}{|c|c|c|}
\hline 目的 & 設計対応 & 備考 \\
\hline 再利用 - 再資源化 & $\begin{array}{l}\text { リサイクル可能な部品・材料の採用 } \\
\text { 解体・分離が容易な構造の選択 } \\
\text { 再資源化への分別容易化 }\end{array}$ & $\begin{array}{l}\text { 品質・コスト } \\
\text { 組み付け時間の短縮 } \\
\text { 材料種統一 } \\
\text { 家電リサイクル法 }\end{array}$ \\
\hline 包装材の対応 & $\begin{array}{l}\text { 再生 ·再利用可能材料の選択 } \\
\text { 収集 - 運搬の容易化, 原料化 }\end{array}$ & $\begin{array}{l}\text { 容器包装リサイクル法 } \\
\text { 材料コストの削減 } \\
\text { 輸送費の削減 }\end{array}$ \\
\hline 廃杗処理容易化 & $\begin{array}{l}\text { 製品等の回収・運搬の容易性 } \\
\text { 製品等の破砕の容易性 }\end{array}$ & $\begin{array}{l}\text { 製品安全は確保する } \\
\text { 処理時の安全性 } \\
\text { 廃掃法 }\end{array}$ \\
\hline 環境保全対応 & $\begin{array}{l}\text { 有害物質の減少化, 代替化 } \\
\text { 有害溶媒等のプロセス使用の削減 }\end{array}$ & $\begin{array}{l}\mathrm{PL} \text { 問題・PRTR } \\
\text { グリーン調達 }\end{array}$ \\
\hline 省資源化 & $\begin{array}{l}\text { 製品の小型・軽量化 } \\
\text { 再生資源の積極利用 }\end{array}$ & 製品コストの削減 \\
\hline 省エネルギー化 & $\begin{array}{l}\text { 製品使用時の省エネルギー化 } \\
\text { 製品製造時の省エネルギー化 }\end{array}$ & $\begin{array}{l}\text { 製品コストの削減 } \\
\text { LCA 的考察 } \\
\text { 省エネ法 }\end{array}$ \\
\hline 長期使用化 & $\begin{array}{l}\text { 長寿命化 } \\
\text { 修理‧交換が容易な構造 }\end{array}$ & $\begin{array}{l}\text { 長期品質保証 } \\
\text { 寿命予測技術 } \\
\text { 低毒性添加剤開発 } \\
\text { ユニットモジュール化 }\end{array}$ \\
\hline 総合評価 & $\begin{array}{l}\text { 各項目ごとに従来製品との比較によ } \\
\eta \text { 得点を付け, 全項目の総合得点を } \\
\text { 算出して評価 }\end{array}$ & $\begin{array}{l}\text { ライフサイクルインパクト分析 } \\
\text { コスト・品質・安全の確保 }\end{array}$ \\
\hline
\end{tabular}

佐藤長光氏が日本電気制御機器工業会技術資料を基に編集されだものを参照して編集した

表 5 ゴム工業に関係するPRTR の対象候補物質

\begin{tabular}{|c|c|}
\hline 亜鉛化合物 & ホルムアルデヒド \\
\hline アクリロニトリル & マンガン化合物 \\
\hline アンチモンおよびその化合物 & エピクロロヒドリン \\
\hline エチレンオキシド & 酸化プロピレン \\
\hline 塩化水素 & クロロプレンモノマー \\
\hline 塩素 & MOCA \\
\hline 塩化ビニルモノマー & ジフェニルメタンジイソシアネート \\
\hline キシレン & フェニレンジアミン類 \\
\hline 有機塩素系溶媒各種 & イソプレン (モノマー) \\
\hline 多環芳香族炭化水素類 & コバルトおよびその化合物 \\
\hline トルエン & スチレンモノマー \\
\hline 鉛化合物 (ポリスルフィド系ゴム, ウレタン関係) & ニトロソアミン類 \\
\hline テトラメチルチウラムジスルフィド & 塩化シアヌル \\
\hline 1，3ブタジエン(モノマー) & 二硫化炭素 \\
\hline DOP & イソプロピルアルコール \\
\hline \multirow[t]{2}{*}{$\mathrm{DBP}$} & MEK \\
\hline & $\mathrm{BHT}$ \\
\hline
\end{tabular}

環境庁 PRTR 技術検討会報告書(1998年 5 月)より抜粋 
表 6 環境ホルモンとして疑われている物質 (抜粋)

\begin{tabular}{ll}
\hline ダイオキシン類 & 可塑剂類(下記 $)$ \\
トリブチルスズ & DOP \\
アルキルフェノール & $\mathrm{DBP}$ \\
ベンゾフェノン & $\mathrm{DEP}$ \\
ベンゾピレン & $\mathrm{BBP}$ \\
スチレンダイマー,トリマー & $\mathrm{DPP}$ \\
4 -オクチルフェノール & $\mathrm{DHP}$ \\
ノニルフェノール & $\mathrm{DPRP}$ \\
ビスフェノール A & $\mathrm{DOA}$ \\
\hline
\end{tabular}

筏義人：環境ホルモン, 講談社ブルーバックス (1998)より 抜粋

このほかジチオカバーメート系殺菌剤, 有機塩素系殺虫剤 など

付けの有無はさておいて，“疑わしきは使用せず” との態度を取っている．塩ビや約 70 種あるとい われる環境ホルモン (外因性内分泌かく乱化学物 質)に対する態度がその典型である(表 6 ).

5 ）廃棄とリサイクルを常にシステム的，全体的 な観点から考えること．部分最適はかえって環境 を悪くすることもありうる．マテリアルリサイク ルか，サーマルリサイクルかはこうした検討が必 要. 2000 年から容器包装リサイクル法が全面的 に適用されるほか，家電リサイクル法への対応も 必要となる，廃棄物処理に関する法と罰則は強化 される一方であり，その動向は常に把握しておく 必要がある。

6 ）製品開発の場合，摇りかごから墓場まで，ラ イフサイクルアセスメント的思考を必ずするこ と.ライフサイクルアセスメントに関しては後述 する。

7 ）組織は環境や資源・エネルギーの有効利用, 廃棄やリサイクルに関し絶えざる改善が可能なマ ネジメントシステムを構築し, 目標管理, PDCA (Plan Do Check Act)，責任と権限の明確化をは かること.マネジメントシステムの構築は前述の グリーン調達においても要求されている.

現在の経済学はいずれも資源，エネルギーの有 限性や廃棄といった価值の衰失を大きな前提とは していない ${ }^{11)}$. 資源・エネルギー消費の増大を伴 わない経済成長は従来の概念からは生まれにく い.しかし, 従来型産業が近未来に不可能になる ことはすでに述べた。また，現実に知識集約型産 業へのシフトによって，エネルギー消費の増大な く経済成長している国が出始めている，更に欧州
を中心にファクターテン又はファクターフォーと いった概念が誕生している。これは現在の先進国 における資源・エネルギーの使用を 4 分の 1 ある いは10 分の 1 にしよjというもので12)，生き残 りのための一提案であり, 新しい経済学や指導原 理の一つの基盤となることを期待したい. また， 我々の現在の生活スタイルが環境との調和のなか で，どこまで許容されるかも殆んど検討されてお らず，感覚的な議論が横行している，個人による 主観の幅が広く困難な課題ではあるが, 研究と社 会的合意形成に向けて動き出す必要がある. 江戸 時代に戻れというのは極論としても, 現代生活の 水準を落とさずにエネルギーの $25 \%$ 削減は可能 という報告もある ${ }^{13)}$. 生活ス夕イルはもとより, 産業構造の転換は痛みを伴う。特にそれが雇用の 削減につながる場合, 生活権の侵害となるので, いかに必要性を説いても総論賛成, 各論絶対反対 となるのは炏を見るより明らかである。（一例と して 1997 年 1 年間の海外旅行者は約 1700 万人と いわれる。このエネルギー消費と二酸化炭素放出 は莫大なものがある。しかし，こうした産業にか かわる人の生活権を考慮しないで問題の解決を図 ることは難しい). 受け皿として広義の環境改善 産業，事業を早期に準備し，テイクオフさせる必 要がある。食糧安全保障事業なども既存の枠組み ではなく，新たな形態のもとに考えられて良いと 思う。自給率の向上は時間を要し, 貿易上の問 題, 価格の高騰を招く恐れはある。しかし信じら れないほど巨額の，公的資金を特定業界に注ぎ込 んだことを思えば不可能とはいえないであろう。 環境問題の解決, 産業転換は雇用創出が鍵といえ る. 既得権や権益への執着も実は環境問題の本質 にかかわっている，人口論で名高いマルサスは， この点を 200 年も前に看破している ${ }^{14)}$.

\section{2 グリーン調達とエコラベル}

今後のもの作りで留意すべき事項としてグリー ン調達の動きと，エコラベルに関する国際規格の 規定がある、詳細は文献を参照願いたい ${ }^{15,16)}$ がグ リーン調達は環境に配慮した製品の優先購入の仕 組みで，北欧に端を発し日本でもコピ一機など事 務機械業界を始めとして相当数のメーカーが宣言 をしている．官公庁へも広がりを見せつつある。 そのポイントは部品供給業者などが環境に対する 継続的改善を可能にするマネジメントシステムを 構築しているか，その予定があること，指定物質 
表 7 エリクソン社の使用禁止物質と使用制限物質

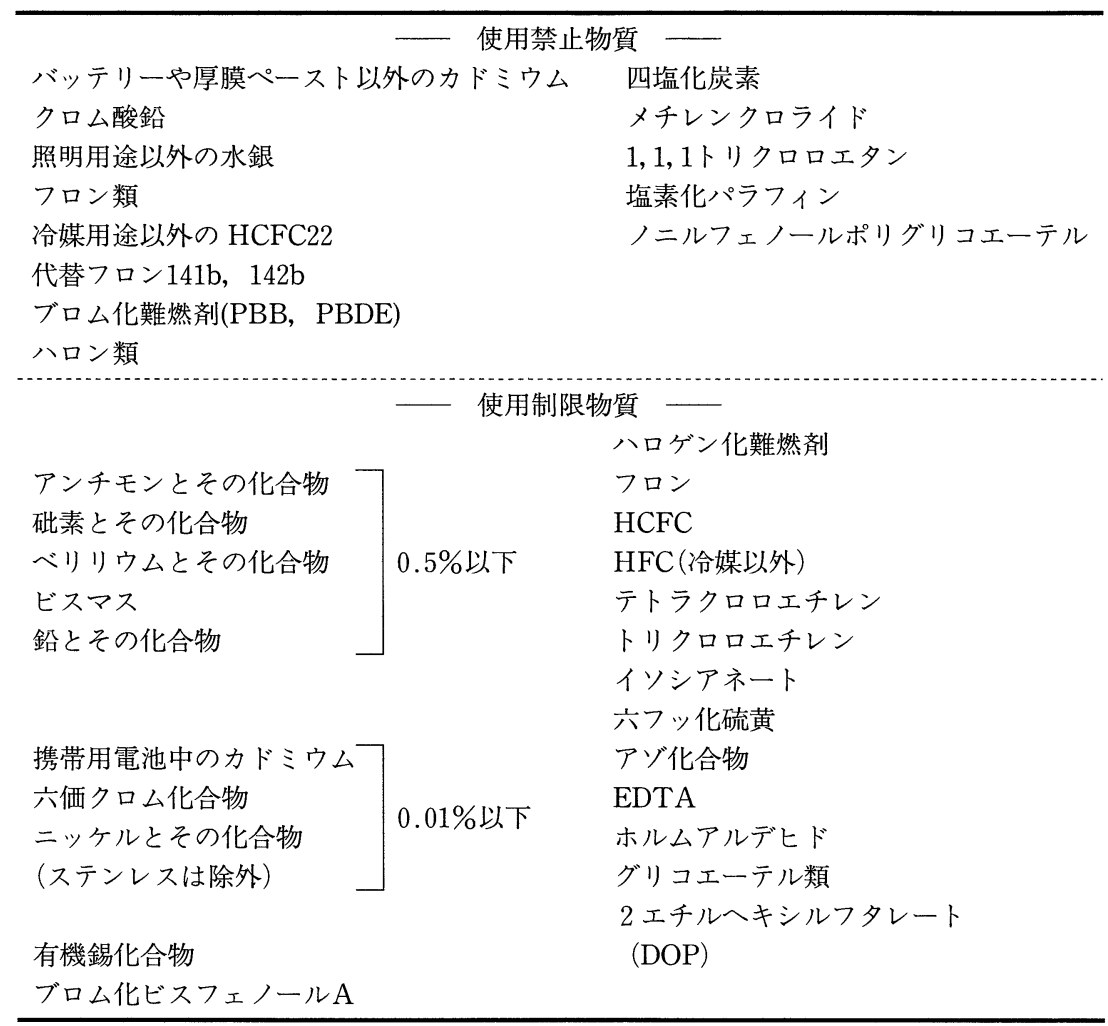

の不使用，又は管理下での使用が保証されること である，各社の内容は大同小異であるがスウェー デンエリクソン社のリストの一部17)を表 7 に示 す。各社は世界中からの供給先を視野に入れ，膨 大なデータベースを構築中の模様である．設計者 が端末で環境, 品質, 価格をにらんで部品や材料 を指定する仕組みが確立すれば，これまでの購買 のありかたはかなり変質すると見て良い。人脈等 に甘えたやりかたは通用しにくくなる．本年の 3 月になって, 家電の旗頭の松下電器がグリーン購 入を発表し, 自動車の雄トヨ夕自動車は間接的な 表現ながらグリーン購入に近いアナウンスをし た ${ }^{18)}$ 。一方，エコマークは，環境に配慮した商品 に「地球にやさしい」(図 3 )などのマークをつけ ることを認め，商品の流通を促進することで環境 改善を図るものであるが，今年は関連する ISO 規格のいくつかが相次いで発行される見込みであ る。今後の産業においてグリーン調達, エコマー クにおいてライフサイクルアセスメント (LCA)

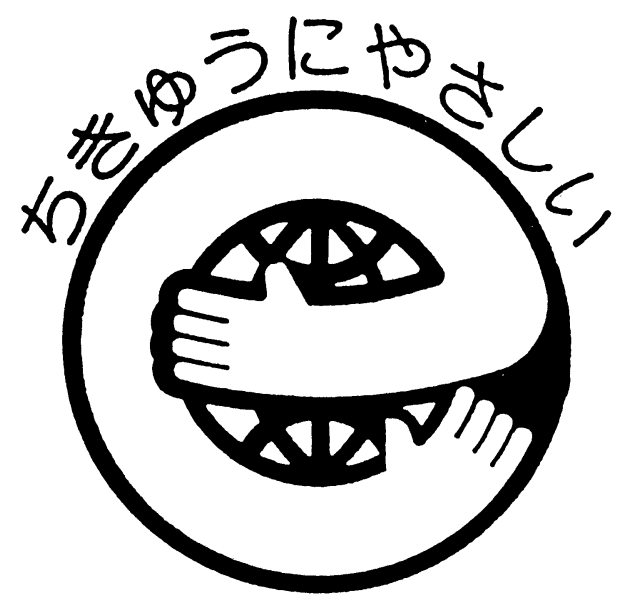

図 3 我が国のエコマーク

が果たす役割は大きい。

3.3 ライフサイクルアセスメント

ライフサイクルアセスメントに対する理解は今 
後の技術者，営業などにとって不可欠といえる. 最近では各種の手引書も発行され ${ }^{19,20)}$ 初期の頃最 大の障害であったデータベースの不備も大幅に改 善されてきたほか, 解析ソフトも内外十指を超え るものが市販されている。 また，LCAの適用も 拡大しつつあり, 廃棄物のマネジメント, 農作物 などにも及んでいる ${ }^{21)}$. LCAに関して詳しく述 べる紙数がないので簡単に述べる，製品を例にと ると「摇りかごから墓場まで」，すなわち原料の 採取から製造, 流通, 使用, 廃棄(リサイクル)を 含む全工程における物質の出入りを定量的に調べ あげて合算し，環境に対する影響を明確にし，改 善などにつなげようとする手法である。しかしこ れはあくまで手法の一つであり，また万能なわけ ではない，LCA を実施する目的，背景，範囲の 明確化, 用いるデータの信頼性, 結果の解䣋など に細心の注意が必要である．結果の第三者向け使 用は重要な経営判断事項と考えるべきで, 数字が ひとり歩きする危険も充分考慮する必要がある. 国際規格はISO 14040，14041 がすでに発行さ れ，前者はJIS 化されている．本年は更にほか の個別規格の発行が見込まれている.

\section{4 . タイヤ・ゴム工業の課題}

ゴムは高分子材料中最も歴史の古い材料に属 し，現代社会に不可欠な材料として少しも価值が 減じていない．量的にはゴムをはるかに凌駕して しまったプラスチック材料も，多くは互いに置換 可能か代替材料の出現で消長があるが，ゴムの絶 対需要はあまり変化していない.ゴムの世界でも いまだに加硫ゴムの性能を凌ぐ熱可塑性ゴムは誕 生していない. 天然ゴムなどは代表的なバイオマ ス材料であり，かのジャンボ機も天然ゴムを一成 分材料とする夕イヤなしには離着陸不可能であ る。しかし，ゴム産業は古いがゆえに多くの課題 も抱えている. 課題の例を列挙してみると,

1) 加硫工程はじめ, 練りゴムの加工時熱入れ, 接着剂の焼きつけなど，かなりの化石エネルギー を使用している。

2 ）原料における石油化学製品依存率が高い

3 ）多くの薬品，オイルなどを使用しており，顕 在化していないリスクを背負っている面がある.

4) ウレタンなどでは塩化メチレンなど，人体, 環境への影響が懸念される有機塩素系溶媒の使用 比率が高い。また，接着剂，塗料に用いられてい
る溶剂，ゴム用揮発油，など一部ではいまだ回収 されていない有機溶媒の使用もある.

5 ）夕イヤなどはサーマルリサイクル，再利用が 約 $90 \%$ といわれるが，そのほかのゴム製品のリ サイクル法を含めなお改善の余地がある。

6 ）製品設計は製品使用初期に焦点が当てられて おり，サービスライフ全般にわたっての設計は部 分的にしか行われていない.

以上のような課題に対しては無論多大の努力が なされ, 加硫促進剂, 老化防止剂などの労働安全 上の問題もより安全な物質に移行している. 大手 の会社では 2000 品目の原材料に関して管理シス テムを構築済みと伝えられている。 ウレタン発泡 におけるノンフロン化もほぼ完了している，熱可 塑性ゴムは夕イヤのような高度な性能を要求され る製品には相変わらず採用は困難であるが，工業 用品などではこれを用いた場合のエネルギー上の 利点が定量的に評価されるようになり出した ${ }^{22)}$.

種々の合理化，効率化に対しても限界まで努力が 積み重ねられてきている。 しかし，個別の対応や 部分最適化ではもはや大きな改善は難しい. 全体 をシステム的に，また可能な限り定量的に，ライ フサイクル全般にわたっての把握, 解析, 改善が 今後の鍵となる。その手法としては前述のライフ サイクルアセスメント (LCA) 的思考などが有効 である。また，ニューラルネットワークなどコン ピュータシミュレーションとの複合も有効であろ $j^{23)}$. 最近夕イヤ業界においても LCA 的解析が 行われるようになり ${ }^{24)}$ ，一定の仮定の下ではある が電気製品同様，使用時のエネルギ一消費が大き いことが報告されている。低燃費夕イヤの開発が 今後とも重要であることを示している．更に多く のプロセス，製品に関し，実施例が増えることを 期待したい。また，業界としても産業環境管理協 会の LCA プロジェクトのデータベース構築に協 力をしている．繰り返しになるが今後取り組むべ き技術課題を列挙すると，

1）エネルギー消費の削減と使用効率化

2 ）天然ゴムの使用拡大(化石資源の有効利用)

3 ) 長寿命化(耐摩耗性向上, 性能変化の少ない ゴム材料設計)

4 ）低燃費夕イヤ用ゴム材料，高耐摩耗ゴム材料 の開発

5 ）リサイクルと廃棄に関する LCA 的考察

6 ）添加剂の総点検と先手を打った代替技術の確 
立(積極的な情報開示を含む)

7 ) 有機溶媒の使用削減，又は廃止，および非溶 剂型接着剂，接着技術の確立

8 ）添加剤や，溶媒などの管理システムの確立

9 ）製品ライフサイクル全般にわたる物質収支と 環境影響評価

10）環境に配慮した製品の積極的開発

環境に配慮した製品の例として，低フロン透過 自動車用エアコンホースの開発がある ${ }^{25)}$ ．筆者の 知る限り，フロン規制の本格化に最も迅速に対応 した商品の一つであり，各社が開発した。このほ か自動車用防振ゴムの金属部分の樹脂化，産業廃 棄物埋め立て処分場用ゴムシートなど，ゴム製品 は環境改善に関連してまだまだ多くの新商品開発 が可能と思われる。

\section{5.おわりに}

以上のような課題への取り組みに際してはトッ プの強いリーダシップの発揮と経営資源の用意な くしては大きな改革は進まない。推進には継続的 で合理的なマネジメントシステムの確立は重要 で，ISO 9000，14000などの導入がそのきっかけ になることを期待したい．業界全体の更なる協 調，共同作業，情報交換が特に化学物質の副作 用，LCA のデータベース構築などに関しては重 要であろう。最後に発展途上国における物作りに 一言ふれておきたい. 円高時代には海外発展途上 国への生産シフトが盛んであったが，これらの国 で環境上の法規などの制約が少ないと思うのは必 ずしも正しくない，最近ではむしろ海外からの新 規建設には新しい基準が適用され，極爰厳しい ことが少なくない．また，「先進国市場はもはや 大きく成長しないが，“未だ中国市場がある，イ ンド市場がある゙」という考え方は非常な環境り スクを背負っていることをはっきり認識しなけれ ばならない，両国の 20 億を超す民が先進国並み の資源・エネルギー消費をしたら，直ちに地球の 資源・エネルギー・環境容量をオーバーし，人類 の共倒れは必至である。これらの国で物作りをす るのであれば，画期的な環境技術，効率，生産方 式で臨む必要があろう。

本資料の要旨は 1998 年 11 月，日本ゴム協会関
東支部主催の「第 39 回 秋期ゴム技術講習会」 で紹介した，論旨が支離滅裂になってしまったこ とをおわびしたい．また，京大粷谷信三教授，三 菱化学市原祥次氏には貴重な著作や資料のご提供 を受けたこと感謝する。

\section{参 考 文 献}

1）石 弘之：地球環境報告II，岩波新書，(1998）

2) Hansen, J.: 日本経済新聞 1998 年 8 月 17 日付記事

3 ） 日本経済新聞：11月 28 日 (夕刊) 記事(1998)

4) $\mathrm{CNN}$ ニュース: 1998 年 12 月 30 日報道

5 ） マーシャル研究所：温室効果問題に関する科学的見通 し(1989)

6 ）環境庁・外務省監訳：アジェンダ 21 , (社)海外環境協力 センター (1993)

7 ）中西準子：リスク論から見るダイオキシン問題，塩ビ とポリマー，38，1 (1998)

8 ）レスターブラウン，今村奈良臣訳「食糧破局」，ダイ ヤモンド社 (1996)

9 ）川島博之：人類生存のための化学，中杉・水野編 p.30 大日本図書 $(1998)$

10）佐藤長光：私信

11）植田和弘：環境経済学への招待，丸善(1998)

12）山本良一監訳：エコ・エフィシエンシーへの挑戦，日 科技連出版社 (1998)

13）ユーリッ七研究所 (独)：化学工業日報, 12 月 10 日付 記事 (1997)

14）マルサス「人口論，世界の名著 $34 」$ 中央公論社 (1969)

15）森下研編：エコラベルとグリーンマーケティングのす べて，化学工業日報社 (1998)

16）産業環境管理協会：環境ラ゙ベル，丸善(1995)

17) Ericsson 社 : Supplier Environmental Requirement -a life Cycle Approach-(1998)

18）トヨ夕自動車：環境に関する調達ガイドライン, (1999. 3.24)

19）未踏科学技術協会エコマテリアル研究会：LCAのす べて：工業調査会 $(1996)$

20）LCA 実務入門編集委員会：LCA 実務入門産業環境管 理協会 (1998)

21）未踏科学技術協会ほか主催：第 3 回エコバランス国際 会議講演集 $(1998,11$ 月筑波)

22）粷谷信三：ゴム材料科学序論：日本バルカ工業(1993)

23）坂本国輔：㭘查技術，p.23，9月号(1997)

24）日本ゴム工業会：タイヤのインベントリー分析試行 (1998)

25）中内，加藤，鉜本，大山，神原：自動車技術， 45, 128 (1991 年 11 月) 